\title{
PENDIDIKAN MADRASAH DALAM NEW NORMAL
}

\author{
Ahmad Taufik, Dedi Heriansah
}

STAI Bumi Silampari Lubuklinggau, MAN 1 Lubuklinggau ahmadtaufik201902@gmail.com,dediheriansah@gmail.com

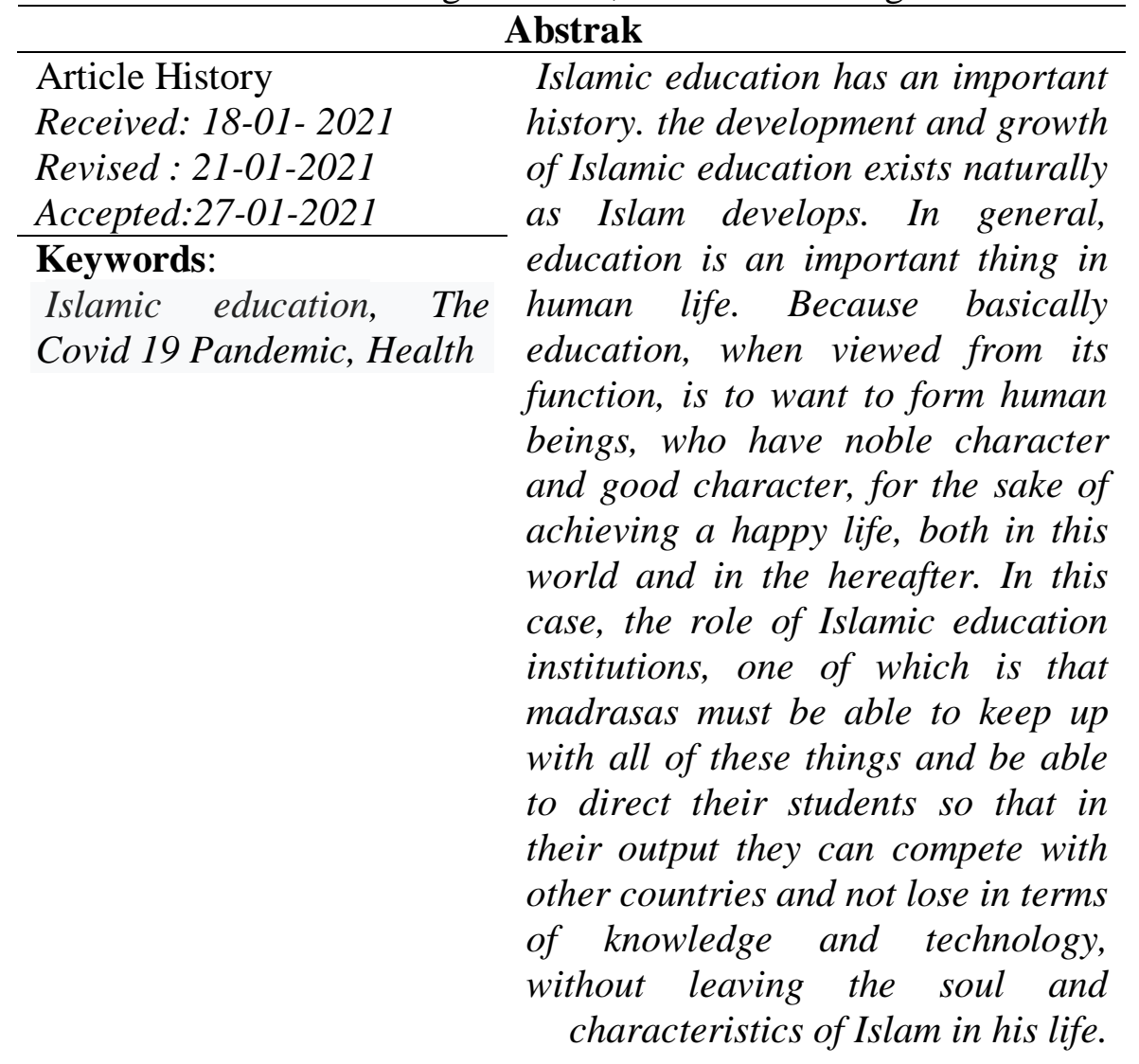

\section{Pendahuluan}

Dalam perspektif historis, Indonesia mendapat julukan sebagai negeri muslim yang unik, disebabkan secara tata letak Indonesia berada jauh dari negara mekkah (tempat wahyu ajaran Islam). Pengakuan dunia terhadap Indonesia terkait pemeluk umat muslim terbanyak yangmana Indonesia didalam catatan sejarah masuknya ajaran-ajaran Islam sekitar abad ke tujuh. Dengan bukti inilah Indonesia bisa mengembangkan penyebaran Islam seantero nusantara. Pemahaman akan ajaran Islam dilalui terbentuknya bentuk 
pendidikan dari sebuah pesantren (Sarijo, 2000: 28). Dengan karakter pesantren yang khas "religius oriented", pesantren terbukti mencetak para siswa ataupun santri dalam memahami nilai-nilai dasar keagamaan ajaran Islam yang kaffah. Para santri dibawah asuhan sosok kiyai tidak juga paham tentang nilai ajaran Islam, santri juga harus bisa mengapresiasikan pengetahuannya dengan menyebarkan dan mempertahankan nilai sesuai ajaran agama Islam.

Masyarakat dunia kini disibukkan dengan upaya-upaya agar dapat terhindar dari virus COVID 19. Masyarakat dunia dikejutkan adanya wabah COVID 19 yang sedang gencar dikabarkan bagi seluruh dunia, begitu juga negara Indonesia merasa sangat terganggu wabah Corona Virus Disease atau COVID 19. Beralih pada sektor pendidikan, upaya pemerintah untuk memutuskan rantai penyebaran COVID 19 yaitu dengan penutupan sementara lembaga pendidikan (Ahmad Taufik, Elghiroh: September 2020). Pastinya gejolak nilai perbandingan dari model pendidikan sekolah umum dan pendidikan sekolah Islam telah membawa makna tersendiri dalam memajukan sendi pemahaman kepuasan nilai secara ajaran Islam. Dualisme model pendidikan yang konfrontatif telah menggugah anggapan aspek kemajuan pendidikan Islam yang bisa unggul dalam nilai norma kemasyarakatan dimulai sejak awal abad dua puluh. Gerakan reformasi tersebut mengubah tendensi pola pembelajaran yang sudah ada dikalangan pesantren kombinasi sesuai harapan masyarakat (Toha dan Mu'thi, 2008: 16).

Corak model pendidikan kemajuan yang ada dalam pesantren terkombinasi ini segera diikuti oleh para pakar dalam memajukan nilai pendidikan disertai dengan ajaran Islam terjadi baik pelosok seluruh pulau Jawa juga pelosok di luar pulau Jawa. Dari sinilah embrio madrasah lahir pertamakali. Era persaingan globaliasi, adanya trend pendidikan bahsannya nilai pengetahuan dalam diri manusia dapat dimulai dan dikembangkan dari dunia pendidikan dan latihan

Secara terus menerus dengan beragam jenis, jenjang, sifat dan bentuknya. Pendidikan negara Indonesia adalah corong terdepan dalam kualitas pendidikan Nasional yang diinginkan dari seluruh masyarakat Indonesia. Perlu diilhami munculnya madrasah adalah salah satu tujuan mulia dalam mengokohkan akidah keyakinan dari masyarakat, dan memiliki nilai luhur akan ajaran Islam yang harus diikuti dan dilaksanakan dalam kehidupan. 


\section{Metode Penelitian}

Penulis melakukan penelitian dengan penelitian kualitatif diproses analisis dokumen data. Kajian dokumen dianggap sebagai analisis dokumen, yang terdiri buku, artikel-artikel, internet dan bahan-bahan yang sesuai dengan penelitian. Adapun cara-cara dalam pengumpulan datanya. Pertama, melalui kajian kepustakaan yang sesuai dengan bahan yang akan diteliti. Kedua, setelah data-data telah diperoleh oleh peneliti, maka selanjutnya menganalisis datanya melalui metode deskriptif sesuai dengan pemahaman penulis dalam melakukan kajian ini.

\section{Pembahasan}

\section{Eksistensi Madrasah dalam Pendidikan}

Munculnya madrasah di negara kepulauan Indonesia dipandang lebih muda dibanding munculnya lembaga yang disebut pesantren. Madrasah lahir pada abad 20 yang didirikan dari perkumpulan para siswa yang diikuti keinginan orang tua dalam menyedikan wadah penyebaran ajaran Islam (Malik Fadjar, 2008: 23). Madrasah berdiri atas inisiatif dan realisasi dari pembaharuan sistem pendidikan Islam yang telah ada. Pembaharuan tersebut, menurut Karl Sternbrink (1986), meliputi tiga hal, yaitu:

1. Usaha sadar menyempumakan sistem yang diberlakukan pesantren,

2. Penyesuaian identitas sistem pendidikan barat, dan

3. Capaian dasar pemikiran bisa menjembatani baik pesantren maupun sistem pendidikan barat.

Madrasah sebagai lembaga pendidikan Islam kini ditempatkan sebagai pendidikan sekolah dalam sistem pendidikan nasional. Munculnya SKB tiga menteri (menteri agama, menteri pendidikan dan kebudayaan, dan menteri dalam negeri) menandakan bahwa eksistensi madrasah sudah cukup kuat beriringan dengan sekolah umum. Disamping itu, munculnya SKB tiga menteri tersebut juga dinilai sebagai langkah positif bagi peningkatan mutu madrasah baik dari status, nilai ijazah maupun kurikulumnya (Malik Fadjar, 2008: 13). Salah satu diktum pertimbangkan dari SKB adalah dapat menghasilkan mutu pendidikan yang baik dari sebuah madrasah dan para siswa yang sudah selesai studinya bisa melanjutkan sistem 
pendidikan yang dikelola oleh sekolah-sekolah umum sehingga langkah analogi prinsip yang ada di sekolah umum harus dijadikan kurikulum di lingkungan madrasah.

\section{Peran Masyarakat dalam Era Globalisasi}

Munculnya kebijakan otonomi daerah dan desentralisasi dalam bidang pendidikan yang bertujuan untuk memberi peluang kepada peserta didik untuk memperoleh keterampilan, pengetahuan, dan sikap yang dapat memberikan kontribusi kepada masyarakat, tidak mengagetkan para pengelola madrasah. Madrasah juga lebih survive madrasah juga lebih survive dalam kondisi perubahan kurikulum yang sangat cepat, karena kehidupan madrasah tidak taklid kepada kurikulum nasional. Manajemen desentralisasi memberikan kewenangan kepada sekolah untuk melaksanakan PBM sesuai dengan kebutuhan yang dikondisikan untuk kebutuhan lokal.

Dengan demikian, maka madrasah mendapatkan angin segar untuk bisa lebih exist dalam mengatur kegiatannya tanpa intervensi pemerintah pusat dalam upaya mencapai peningkatan mutu pendidikannya. Melalui proses belajar mengajar yang didasari dengan kebutuhan lokal, kurikulum tidak terbebani dengan materi lain yang sesungguhnya belum atau bahkan tidak relevan bagi peningkatan pengetahuan dan keterampilan peserta didik pada jenjang tersebut. Efektivitas proses belajar mengajar diharapkan bisa tercapai sehingga menghasilkan prestasi belajar yang lebih tinggi.

Adapun meningkatnya keterlibatan pemerintah dalam pendidikan menyebabkan para pengelola madrasah memfokuskan pada program-program tambahan sebagai sarana meningkatkan kualitas pendidikan. Program remidial dan kursus untuk meningkatkan perkembangan kognitif, sosial dan emosional dari siswa yang berkemampuan rendah dalam taraf perekonomian dan hasil belajar merupakan program-program kompensasi, bukan untuk menggantikan program-program yang ada (Abdul Rachman Assegaf, 2011: 2).

Sebagai lembaga pendidikan yang lahir dari masyarakat, madrasah lebih mudah mengintegrasikan lingkungan eksternal ke dalam organisasi pendidikan, sehingga dapat menciptakan suasana kebersamaan dan kepemilikan yang tinggi dengan keterlibatan yang tinggi dari masyarakat. Keterlibatan masyarakat bukan lagi terbatas seperti peranan orang tua siswa (POMG) yang hanya melibatkan diri 
di tempat anaknya sekolah. Melainkan keterlibatan yang didasarkan kepada kepemilikan lingkungan. Sesuai dengan jiwa desentralisasi yang menyerap aspirasi dan partisipasai masyarakat dalam pengembangan dan peningkatan kualitas pendidikan, masyarakat dituntut untuk memiliki kepedulian yang tinggi memperhatikan lembaga pendidikan yang berada di lingkungan setempat. Hal ini dapat menumbuhkan sikap kepemilikan yang tinggi dengan memberikan kontribusi baik dalam bidang material, kontrol manajemen, pembinaan, serta bentuk partisipasi lain dalam rangka meningkatkan.

\section{Peran Pendidikan Islam Era Globalisasi}

Indonesia adalah bagian dari negara di dunia yang banyak dianut oleh penduduk muslim, yangmana dalam hidup dan kehidupan manusia tentu mengalami globalisasi berupa aspek ekonomi, politik, budaya, sosial, serta ranah pendidikan. Tidak bisa dipungkiri dilema akibat globalisasi yang menggiring generasi muda Islam mengikuti tata rujukan dari negara barat, misalnya model seni dalam berbusana, jenis makanan-makanan yang higinies, pergaulan muda-mudi yang trend dibanding memakai tata karma dan nilai-nilai keislaman. Jadi, inilah kejadian-kejadian yang bisa dilihat setiap hari sosok panutan dan praktek anjuran dari nilai-nilai keislaman dilaksanakan bagi generasi muda Islam.

Tidak terkecuali ranah pendidikan juga dipengaruhi dari gejala globalisasi bisa diukur baik sisi tujuan, proses jalinan kerjasama antara siswa dan para guru, etika, metode, media pembelajaran maupun bentuk sarana lainnya. Sisi tujuan pendidikan misalnya, ada beberapa kecenderungan yang menggiring sifat materialisme, sehingga implikasi pertama diinginkan dari beberapa orang tua siswa jika telah selesai studinya dari lembaga pendidikan atau sekolah dapat menjadi salah satu gerbang masa depan kehidupannya. Demikian juga berkaitan dalam kurikulumnya, lebih mengarah pada cara pandang yang materialistik (Baharudin, 2011: 8). Itulah agendaagenda yang ada di sekolah para siswa diajak menguasai ilmu (cognitife) saja padahal sinkronisasi dari pengetahuan fokus pribadi mencerminkan dengan nilai-nilai Islam.

Hal lumrah yang sudah menjelma anggapan sudah lumrah pergaulan antara siswa misalnya, bisa dilihat dari media cetak atau elekronik menemukan beberapa siswa standar tabiat kurang baik 
bahkan tidak etis dilaksanakan oleh generasi muda Islam hasil globalisasi yakni banyak pergaulan muda-mudi yang lebih bebas ditemukan dalam berbagai pergaulan pelosok di negeri ini. Seperti misalnya pergaulan antara guru dan siswa, sering mendapatkan informasi hubungan bebas guru dan siswa, jual beli hasil nilai, dan tak jarang adanya para siswa yang masih kurang menghargai banyak guru yang seyogyanya wajib dihormati dan menjadi panutan dalam prilaku. Masih banyak prilaku-prilaku lain sudah biasa ada dalam ranah dunia pendidikan (Depdiknas, 2002: 366).

Dari menghadapi dampak yang dimunculkan oleh globalisasi diatas, bisa jadi alasannya bahwa nilai Islam sebagai hal penting dan strategis. Nilai-nilai Islam disini jadi solusi dalam mengurangi akibat globalisasi dunia barat. Dengan begitu, siswa juga harus dikenalkan dan ditanamkan dari nilai-nilai ajaran Islam terhadap para siswa. Jika ingin mendapatkan kualitas pembelajaran efektif setidaknya disuguhkan melalui etika komunikasi guru saat berada di ruang kelas (Ahmad Taufik, Edification: Juli 2020).

Untuk mengetahui dimana posisi lembaga pendidikan Islam dalm era globalisasi ini, maka terlebih dahulu kita memetakan kekuatan dan kelemahan serta peluang dan tantangan lembaga pendidikan Islam. Dengan mengetahui peluang dan tantangannya, maka pendidikan Islam dapat memposisikan diri secara tepat dalam pergaulan sosio-kultural. Berikut ini akan dipaparkan sejumlah kelemahan yang sekaligus merupakan tantangan yang harus dibenahi oleh lembaga-lembaga pendidikan Islam antara lain sebagai berikut:

a. Kualitas lembaga pendidikan Islam secara umum masih menyedihkan.

b. Citra lembaga pendidikan Islam relatif rendah. Adalah suatu kenyataan bahwa dalam ranking kelulusan lembaga pendidikan Islam umumnya berada didalam urutan dibawah sekolah umum.

c. Kualitas dan kuantitas guru yang belum memadai. Guru adalah kunci keberhasilan dalam pendidikan. Jika gurunya berkualitas rendah dan rasio siswa tidak memadai, maka output pendidikannya dengan sendirinya akan rendah pula.

d. Gaji guru secaara umum masih kecil. 
e. Latar belakang siswa dilembaga pendidikan Islam pada umumnya dari keluarga kelas menengah ke bawah.

f. Tuntutan kompetisi dan kompetensi yang semakin meningkat.

g. Gempuran pengaruh globalisasi asing dalam bidang ekonomi, politik dan budaya yang cenderung menggeser budaya nasional yang religious.

h. Kenakalan remaja yang semakin mengkhawatirkan antara lain dalam bentuk penyalahgunaan narkoba yang semakin meluas.

Tantangan dan peluang yang dihadapi dari berbagai pendidikan Islam jikalau mendidik, membiasakan serta mengakomodir perbuatan-perbuatan yang baik saat para siswa menghadapi era millennium ketiga ini, para siswa bisa melakukan kemajuan zaman dibarengi praktek pengetahuan pendidikan Islam dikemas sesuai kredibilitas keilmuan dalam menu sendi-sendi pendidikan Islam yang diberikan bisa mengajak kecakapan kedewasaan. Untuk itulah, kualitas impian pengetahuan dari pendidikan Islam (madrasah dan sekolah Islam) yang masih mempunyai kualitas rendah, harus adanya pemahaman jelas dalam membangun paradigma keilmuan yang unggul (Baharudin, 2011: 10).

Lebih lanjut menurut Baharudin berprinsip tentang reformasi pendidikan unggul bagi para siswa era millenium ketiga ini ada beberapa hal yang bisa dilakukan, berupa :

1. Ajaran agama yang disajikan bagi para siswa didesain dalam titik tekan bahwasannya ajaran agama bersifat "kesalehan aktual" bukan saja mengenai "kesalehan ritual". Hal ini dianggap mumpuni dan baik dilaksanakan dalam sekolah mengingat millennium ketiga sering terjadinya trust juga oleh kompetisi.

2. Tata kendali dalam ranah pendidikan Islam bisa menggerakan generasi bangsa yang pluralis siap pakai menghadapi ritualitas dari internal maupun eksternal.

3. Pengembangan sifat pluralis sudah menjadi bagian tak terpisahkan mencetak masyarakat madani bisa bersikap demokratis, terbuka dan beradab yang mengerti banyak perbedaan pendapat. 
4. Tujuan masyarakat madani seutuhnya ingin digapai oleh negara ialah memiliki masyarakat yang penuh percaya diri, memiliki kemandirian dan kreatifitas yang tinggi dalam memecahkan beberapa masalah yang dihadapi.

5. Pendidikan disini bagian sentral mengajak para generasi bangsa yang siap berpartisipasi aktif kemajuan globalisasi, hal ini berarti pengetahuan dan keterampilan sebagai tolak ukur dalam mewujudkan relevansi yang akurat dengan trend global tersebut.

Selain memiliki tantangan dan peluang, pendidikan Islam juga harus memperhatikan bagian penting esensi dari nilai diantaranya yaitu: pertama, upaya bisa mengelola mutu sumber daya manusia, dijelaskan tantangan secara internal serta tantangan eksternal mnyeluruh, maka background keunggulan-keunggulan mutlak dari karya para siswa dapat mengerti ataupun adanya penguasaan dari pemikiran sains dan teknologi dan daya saing dari unggulnya sumber daya manusia (SDM) yang ada. Kedua, mendesain kurikulum yang siap pakai era milenium ketiga wawasan masa kini dan masa terdepan. Mencermati sumber tantangan bagi para siswa mengenai globalisasi diatas, maka sudah sewajarnya tidak mustahil pendidikan Islam dapat berkontribusi sangat penting dan rencana strategis.

\section{Simpulan}

Era globalisasi yang dialami oleh para siswa ada titik temu dari nilai-nilai positif maupun nilai negatif yang dijadikan sisi capain dari global tentunya sikap mental dari tiap individual bisa menginstrusikan dan memiliki sifat bertahan dan mampu mengelola prinsip mengembangkan diri secara sadar, khususnya tata kelola unggul dilahirkan dari pemikiran lembaga pendidikan Islam bisa berdaya inspiratif dari berbagai sekolah-sekolah yang sudah berdiri kokoh dan terkesan bahwa lembaga pendidikan Islam sebagai solusif zaman sekarang.

Dengan meningkatnya heterogenitas pemikiran yang sudah terjadi dari kalangan masyarakat, dan informasi-informasi berkembang yang diakui oleh masyarakat modern, dan munculnya berbagai kemajuan dalam aspek industri sifat materialistik, memiliki makna bahwa segala lini dari nilai individual diukur dengan ukuran- 
ukuran ekonomi dan kebendaan, maka para siswa harus mudah membaca peluang rencana yang akan dilaluinya. Disinilah tuntutan pendidikan Islam yang diinginkan oleh sebagian masyarakat bisa membantu kerasnya dan kuatnya pengaruh globalisasi yang sudah memiliki nilai-nilai tersendiri. Oleh karenanya, para siswa harus sigap yang ditopang oleh intelektual yang tinggi, kepribadian yang tangguh, akhlak mulia, serta iman yang tangguh. Lembaga pendidikan Islam, yang ada di sekitar masyarakat berupa: Kualitas lembaga pendidikan Islam masih belum optimal dan belum sesuai keinginan capaian nilai masyarakat, Citra lembaga pendidikan Islam relatif rendah. Adalah bentuk kenyataan indikasi ternyata masih ditemukan alumni lembaga pendidikan Islam umumnya belum memiliki kualitas unggul daripada sekolah umum, Kualitas dan kuantitas guru yang belum memadai. Guru adalah tonggak keberhasilan dalam mengoperasionalkan ideide cemerlang terhadap para siswa. Jika guru masih mempunyai kualitas rendah dan rasio siswa tidak memadai, maka alumni yang dihasilkannya juga sangat rendah pula, Gaji Guru masih kecil dan belum mencukupi rasio nilai sejahtera, masih banyak latar belakang para siswa yang mengikuti pembelajaran dalam lembaga pendidikan Islam pada umumnya dari keluarga ekonomi rendah sehingga para siswa memahami pembelajaran sesuai retorika pendidikan orang tuanya. 


\section{DAFTAR PUSTAKA}

Al-Abrasyi, Moh. Athiyah. 2000. Dasar-dasar Pokok Pendidikan Islam. Jakarta: Bulan Bintang.

Assegaf, Abdul Rachman. 2011. Filsafat Pendidikan Islam:

Paradigma Baru Pendidikan Hadhari Berbasis

ntegratif-Interkonektif. Jakarta: Rajagrfindo.

Baharudin. 2011. Pendidikan Islam dan Isu-Isu Sosial. Yogyakarta Kurnia Kalam Semesta.

Depdiknas. 2002. Kamus Besar Bahasa Indonesia. Jakarta: Balai Pustaka.

Dradjat. 2001. Membina Nilai-nilai Moral di Indonesia. Jakarta: Bulan Bintang.

Dhofier. 2002. Tradisi Pesantren. Jakarta: LP3ES.

Fadjar. 2008. Madrasah dan Tantangan Modernitas. Bandung: Mizan.

Fadjar, Malik. 2008. Madrasah dan Tantangan Modernitas. Bandung: Mizan.

Nata, Abudin. 2000. Pengaruh Globalisasi Terhadap Pendidikan Islam. Bandung: Angkasa.

Sarijo. 2000. Sejarah Pondok Pesantren di Indonesia. Jakarta: Dharma Bakti.

Sternbrink. 1986. Pesantren, Madrasah dan Sekolah. Jakarta: LP3ES.

Taufik, A. (2020). Penguatan Pembelajaran Sistem Daring. ElGhiroh, 22 (02), 81-102.

Taufik, A. (2019). Agama dalam Kehidupan Individu. Edification Journal, 1 (1), 57-67.

Taufik, A. (2020). Interaksi Komunikasi dalam Pendidikan. Edification Journal, 2 (2), 123-132. 